\title{
Employee Perceptions of the Manager Behaviors That Create Follower-Leader Trust
}

\author{
Gus Gordon ${ }^{1, *}$, Ann Gilley ${ }^{2}$, Sherry Avery ${ }^{2}$, Jerry W. Gilley ${ }^{3}$ \& Afton Barber ${ }^{4}$ \\ ${ }^{1}$ Department of Accounting, Finance and Business Law, The University of Texas at Tyler, 3900 University Blvd, \\ Tyler, TX 75799, USA \\ ${ }^{2}$ Department of Management, The University of Texas at Tyler, 3900 University Blvd, Tyler, TX 75799, USA \\ ${ }^{3}$ Department of Human Resource Development and Technology, The University of Texas at Tyler, 3900 University \\ Blvd, Tyler, TX 75799, USA \\ ${ }^{4}$ The University of Texas at Tyler, Department of Human Resource Development and Technology, 3900 University \\ Blvd, Tyler, TX 75799, USA \\ *Corresponding author: Department of Accounting, Finance and Business Law, The University of Texas at Tyler, \\ 3900 University Blvd., Tyler, TX 75799, USA. E-mail: ggordon@uttyler.edu
}

Received: February 18, $2014 \quad$ Accepted: March 7, $2014 \quad$ Online Published: April 29, 2014

doi:10.5430/mos.v1n2p44

URL: http://dx.doi.org/10.5430/mos.v1n2p44

\begin{abstract}
Trust and related concepts are often discussed as representing important behaviors of good leaders. We empirically tested these concepts to obtain insight into what builds trust between leaders and followers from the employee's perspective. This was accomplished through a questionnaire with 409 respondents. The results were tested empirically through both regression and structural equation modeling. Both models indicate a good fit with statistical significance for what these respondents feel build trust with their leader. The behaviors identified in this study as enhancing perceptions of trust in leaders are demonstrated by managers who behave ethically, positively influence organizational culture, treat employees fairly and consistently, encourage employee growth and development, and promote work-life balance. Our results contribute to the extant literature by empirically validating this unique set of behaviors that model trust-building with followers. This should provide practitioners with a guide for trust-building and enable researchers to further develop and test the model and its implications for organizational commitment and performance, as well as form a base for trust scale development similar to Robinson (1996).
\end{abstract}

Keywords: leadership; trust; culture; employee growth and development; work-life balance

Vast amounts of academic research have been devoted to identification of behaviors demonstrated by effective leaders. Trust and related concepts are intuitively woven through the fabric of leadership. Trust is generally considered to be defined through some notion of risk and/or willing vulnerability to the actions of others (Curral \& Judge, 1995; Rousseau, Sitkin, Burt, \& Camerer, 1998).

Leadership is often viewed as a social phenomenon based on interactive relationships between leader and followers (Griffin \& Stacey, 2005). Trust is considered an important element for stable and enduring relationships (Blau, 1964). Additionally, trust is often seen as promoting cooperation among participants in a social system (LaPorta, Lopez-de-Silanes, Shleifer, \&Vishny, 1997). Tyler (2003) also found that trust enables cooperation.

If one considers leadership to represent the notion that followers will willingly seek to obtain the leader's objectives, then cooperation would seem critical. Since trust is believed to promote cooperation, the study of behaviors that create trust will provide important insight into leadership. In fact, Martin (1999) believes the most important element for leadership is the ability to engender trust. Therefore, we believe it is important to obtain insight into what builds trust between leaders and followers. 


\section{Benefits of Trust in Leadership}

Previous research has shown that organizational effectiveness is positively influenced by trust (Golembiewski \& McConkie, 1975; Munn, 1995; Robinson, 1996). Mayer and Gavin (1999) propose that subordinates will be distracted from performance if they believe they cannot trust their leaders. Kramer (1999) concludes that trust reduces social transaction costs in organizations. Gordon (2010) found that trust was important for overcoming cultural differences when managing in Mexico.

Bijlsma and Koopma (2003) claim that trust facilitates discretionary effort on the part of subordinates. Sharkie (2009) argues that discretionary effort, or performance beyond organizational expectations, is vital due to the fact that employment contracts cannot contemplate all of the demands on employees in the very competitive environment that is the current reality. Furthermore, it is postulated that subordinates who feel trusted are more motivated and energized (Fairholm, 1991). Dirks and Ferrin's (2002) meta-analysis of trust in leadership led them to conclude that trust in leadership resulted in favorable work attitudes, citizenship behaviors, and job performance as they had hypothesized.

As noted previously, leadership is considered a social process. In social processes, social capital can be developed. Social capital is the goodwill developed through social interaction that enables and facilitates action (Adler \& Kwon, 2002). Trust has been equated by some with social capital (Fukuyama, 1997), while others (Putnam, 1993) assert that trust is a source of social capital or that that social capital is created through trust (Portes, 1998). Further, it has been theorized that trust can be gained by the leader of followers through establishing a social exchange relationship and showing concern and respect for subordinates (Jung \& Avolio, 2000; Pillai, Schriesheimand, \& Williams, 1999).

Transformational leadership is based on the idea that the leader can transform or change subordinates' values and attitudes so that they perform beyond expectations. Podsakoff, MacKenzie, Moorman, and Fetter (1990) identified six behaviors from previous research that are associated with transformational leadership, which are articulating a vision, providing a behavioral role model, fostering group goals, setting high performance expectations, providing support of individual subordinates, and intellectual stimulation. Podsakoff, et al. (1990) empirically tested the results of a sample of managers in a multinational firm and found that transformational leader behaviors impact organizational citizenship behaviors in an indirect manner and that the effects are mediated through followers' trust in their leader.

In their research on transformational behaviors, Kouzes and Posner (1993) found five factors related to leadership: risk-taking, inspiring a shared vision, enabling others to act, modeling the way, and encouraging the heart. Kent, Crotts and Aziz (2001) in similar research found the following five factors related to leadership behaviors: visualizing greatness, empowering the "we," communicating for meaning, managing one's self, and care and recognition.

Another stream of leadership research developed around the dyadic relationship between the leader and subordinates is known as leader member exchange (LMX). LMX research describes the processes through which relationships develop, and characterizes high LMX relationships as having mutual trust and loyalty (Bauer \& Green, 1996; Dienesch \& Liden, 1986). Brower, Schoorman, and Tan (2000) refine these concepts into a relational model of LMX and interpersonal trust in which the leader and subordinate evaluate the ability, benevolence, and integrity of each as antecedents to trust.

\section{Trust and Leadership}

Both transformational and LMX research rely on trust as an important component to effective leadership (Bass, 1990; Hogan, Curphy, \& Hogan, 1994; Kirkpatrick \& Locke, 1996; Schriesheim, Castro, \& Cogliser, 1999). As noted earlier, trust may be generally defined in a leadership context as a follower's willingness to put him or herself at risk. A model reflecting a subordinate's propensity to engage in behavior that puts one more at risk based on perception of the leader's integrity, capability, or benevolence was developed by Mayer, Davis, and Schoorman (1995).

Trust is considered to be a reinforcing process (Butler, 1991; Zand, 1972) and benevolence and caring are considered to be antecedents to trust (Jung \& Avolio, 2000; Mayer et al, 1995; Pillai, Schriesheim, \& Williams, 1999). Gillespie and Mann (2004) concluded that such transformational leadership behaviors as communicating vision, motivating toward common values, and acting in ways that build respect and confidence in employees accounted for 67 percent of trust by employees in their supervisor.

Martin (1999) states that exercising trust leadership requires the leader to influence followers by tapping into their value systems to build trust and to develop genuine personal relationships. This is accomplished through communication, the leader keeping his or her word, and trusting employees first. Building trust is difficult and time consuming, however. Gilley (2006) proposed a process for building trust-based relationships that included creating an 
environment free of fear while enhancing communications, interaction, acceptance, personal involvement, and honesty.

Dirks and Ferrin (2002) researched the antecedents to trust and found strong relationships with transformational leadership behaviors, organizational support, and interactional justice. Additionally, they found some empirical support for transactional leadership behaviors that deal with equity and fair treatment.

Burke, Sims, Lazarra, and Salas (2007) developed an integrative model of trust in leadership that highlighted characteristics that foster trust in leaders. The behaviors were categorized into three groups: ability, benevolence, and integrity. Ability is further characterized by the leader's success in setting compelling direction and creating an enabling structure. Benevolence is a set of behaviors that create and sustain supportive context, including teaching. Integrity is represented by the behaviors associated with accountability, justice, and value congruence.

Sitkin, Hernandez, and Long (2007) conducted research on three sets of behaviors that they hypothesized would foster trust, which were personal leadership, relational leadership, and contextual leadership behaviors. They defined five characteristics of personal leadership behaviors, which were authenticity, vision, expertise, creativity, and passion. Three characteristics of relational leadership are concern, respect, and procedural fairness. Characteristics of contextual leadership behaviors are coherence and coordination. Their research suggest that contextual characteristics were not significant in and of themselves, and that relational leadership behavior is the central driving factor to creating trust in leaders. Personal leadership behavior was also significant, while all behaviors interacted with relational leadership behavior.

Relational behaviors as defined by Sitkin, et al (2007) include concern and respect. Concern and respect on the part of the leader for followers is akin to the concept of servant leadership first introduced by Greenleaf (1977), who believed that placing the needs and interests of followers above those of the leader revealed true leadership. De Pree (1989) noted that effective leaders help their followers to become all that they can. Twenty separate behaviors, including trust, have been identified as associated with leader servants (Russell \& Stone, 2002). Farling, Stone, and Winston (1999) developed a model of servant leadership that includes vision, influence, credibility, trust, and service.

Gordon and Gilley (2012) developed a trust leadership model that proposed four separate concept-based behaviors that establish and reinforce trust. The behaviors are communication and vision, compassion, promoting a stakeholder view, and equitable reward and recognition.

Trust, an important factor in effective leadership, must be earned and is done so in a social context. Past research has shown that most of the antecedents to trust are associated primarily with transformational leadership-type behaviors (Gillespie \& Mann, 2004; Jung \& Avolio, 2000; Mayer, et al, 1995; Pillai, et al, 1999). In general, these behaviors revolve around the notions of vision (Gillespie \& Mann, 2004), equitable behavior, which includes care and concern (Jung \& Avolio, 2000; Pillai, et al, 1999), motivation (Gillespie \& Mann, 2004), and integrity, which includes ethical behavior (Burke, et al, 2007).

\section{Method}

Our study explored leadership behaviors that impact trust from the perspective of employees. This study was part of a larger study of managerial practices. Subordinate assessments of managerial behavior provide the most accurate ratings of leader performance (Hogan, Curphy, \& Hogan, 1994). This study was part of a larger study of managerial practices. The previously validated survey instrument contained 23 behavioral/content questions about leader/manager behaviors, and nine demographic questions of the respondents.

\section{Research Questions}

To examine the behaviors that impact managerial trust, we designed a study to answer two key questions. First, we explored whether leaders are trustworthy from the perspective of their employees. Second, we identified those behaviors that have the greatest impact on managerial trust, again from the employee's perspective.

\section{Data Collection}

The survey instrument was given to students in MBA and organizational development (OD) masters' and PhD students from five four-year, public universities in diverse locations (Mountain West, Midwest, and South) over eight semesters. Master's and $\mathrm{PhD}$ students were chosen to maximize industry and position diversity, ultimately representing all 
organizational levels (front-line to executive) in manufacturing, service, education, professional, and government entities. The final response rate was $92 \%$ with 409 useable responses.

\section{Measures}

The dependent variable in the study was a perceptual measure of trust. Respondents were asked to specify, in their opinion, how frequently "My manager is trustworthy." Responses were collected using a 5-point Likert-type scale ranging from never (1) to always (5).

The independent variables examined in this study were derived from research on leadership skills and managerial behaviors associated with trust. Using the same 5-point scale, respondents were asked to indicate the frequency with which their supervisor or managers exhibits 14 managerial behaviors, including

- Treats employees fairly and consistently,

- Coaches employees,

- Effectively evaluates employees,

- Appropriately rewards employees,

- Communicates appropriately,

- Effectively implements change,

- Motivates employees,

- Encourages employees' growth and development,

- Involves employees in decision making,

- Treats employees as unique,

- Encourages teamwork and collaboration,

- Is ethical

- Positively influences culture, and

- Promotes work-life balance.

- Creates a hostile or fearful work environment, and

- Is ineffective in his/her position

\section{Results}

The sample size for the survey population was 409 ; with $49.5 \%$ of the respondents reporting being male and $50.4 \%$ female. With regards to age, $60.7 \%$ were younger than $35,35.7 \%$ were between the ages of 36 and 55 , and $3.7 \%$ were older than 55. With regard to position, $38.6 \%$ classified themselves as front-line employees, $27.4 \%$ as supervisor or team leader, $22.5 \%$ as mid-level manager, $7.8 \%$ as senior or executive manager, and $3.7 \%$ as other. With regard to organizational tenure, $23.0 \%$ of the respondents had been employed less than one year, $45.2 \%$ one to three years, $29.6 \%$ four to six years, $6.8 \%$ seven to ten years, and $6.5 \%$ over ten years. By industry, $6.6 \%$ were manufacturing, $30.1 \%$ service, $22.7 \%$ education, $23.7 \%$ professional, $10.5 \%$ government, and $6.4 \%$ non-profit. With regard to organizational size, $30.1 \%$ of firms had less than 100 employees, $18.3 \% 101-500,10.5 \% 501-1,000,12.0 \% 1,001-2,500,4.4 \%$ $2,501-5,000,7.1 \% 5,001-10,000$, and $17.6 \%$ over 10,000 .

Table 1 reports descriptive statistics of employees' perception of their manager's trustworthiness. Respondents indicate that their managers were "never," "rarely," or only "sometimes" trustworthy with a frequency $56.8 \%$, as compared with $53.2 \%$ for "usually" or "always" trustworthy.

Table 1. My Managers is Trustworthy

\begin{tabular}{llllll}
\hline & Never & Rarely & Sometimes & Usually & Always \\
\hline $\mathrm{N}$ & 24 & 48 & 98 & 141 & 98 \\
$\%$ & 5.9 & 11.7 & 24.0 & 34.5 & 24.0 \\
Cumulative \% & 5.9 & 17.6 & 41.6 & 76.0 & 100.0 \\
\hline
\end{tabular}

Note: $\mathrm{N}=409, \mathrm{M}=3.59, \mathrm{SD}=1.145$ 


\subsection{Data Analysis}

Two statistical tools were used to analyze the relationship between the independent variables and the dependent variable "manager's trustworthiness." Linear regression was used to test the individual item measures and structural equation modeling was used to test the combined impact of both positive and negative manager behaviors on trust. Both methods rely upon similar assumptions about the distribution of the data. The dependent variable exhibited a reasonable normal distribution. Additionally, there was no evidence of collinearity (all VIF factors $<3.0$ ).

\subsection{Regression Analysis}

Table 2 reflects descriptive statistics and correlations for the dependent (predicted) variable 'my manager is trustworthy' and the five most significant independent (predictor) variables identified through regression analysis (see Table 3): "ethical," "positive influence on culture," "encourages employees' growth and development," "treats employees fairly and consistently" and "promotes work-life balance." All variables exhibited moderately high correlations with "ethical" and "culture" reflecting the highest correlation with trust at .853 and .782, respectively.

Table 2. Descriptive Statistics and Intercorrelations

\begin{tabular}{llccccccc}
\hline & & Mean & Std. Dev. & 1 & 2 & 3 & 4 & 5 \\
\hline 1. & Trustworthy & 3.59 & 1.145 & & & & & \\
2. & Ethical & 3.77 & 1.002 & $.853^{* *}$ & & & & \\
3. & Culture & 3.33 & 1.117 & $.782^{* *}$ & $.743^{* *}$ & & & \\
4. & Fair & 3.48 & 0.978 & $.749^{* *}$ & $.700^{* *}$ & $.733^{* *}$ & & \\
5. & Employee growth & 3.26 & 1.111 & $.654^{* *}$ & $.580^{* *}$ & $.693^{* *}$ & $.676^{* *}$ & \\
6. & Work-life balance & 3.27 & 1.195 & $.674^{* *}$ & $.614^{* *}$ & $.727^{* *}$ & $.686^{* *}$ & $.633^{* *}$ \\
\hline$* 05$ & & & & & & & &
\end{tabular}

Table 3 reveals the results of multiple regression analysis using a stepwise method of independent variable inclusion, which is appropriate for determining significant influences of multiple independent variables on a single dependent variable (Nunally \& Bernstein, 1994: Vogt, 2005). The stepwise criteria used on the $F$ scores for variable inclusion were $p<.05$ for inclusion and $p>.10$ for exclusion. This resulted in five independent variables that were statistically significant at a minimum of $p<.05$. The order of importance of the variables was "ethical," "positively influences culture," "treats employees fairly and consistently," "encourages growth and development" and "promotes work-life balance." The five independent variables explained $79.7 \%\left(\mathrm{R}^{2}\right.$ adjusted $\left.=.797\right)$ of the variation of the dependent variable "My manager is trustworthy."

Table 3. Regression Analysis $(\mathrm{n}=409)$

\begin{tabular}{lccc}
\hline & $B$ & $S E B$ & $\mathrm{~B}$ \\
\hline Constant & $-.388^{* * *}$ & .106 & \\
Ethical & $.607^{* * *}$ & .041 & .530 \\
positively influences culture & $.174^{* * *}$ & .043 & .169 \\
treats employees fairly and consistently & $.173^{* * *}$ & .044 & .147 \\
encourages employees' growth and development & $.085^{* *}$ & .034 & .082 \\
Promotes work-life balance & $.072^{* *}$ & .034 & .075 \\
\hline
\end{tabular}

\subsection{Structural Equation Modeling (SEM)}

Amos 20.0 was used to estimate the model. The two-step approach recommended by Anderson and Gerbing (1988) was followed. In the first step, confirmatory factor analysis was used to validate the measurement model. In the second step, structural equation modeling was used to evaluate the full model including both the measurement and structural model. 


\subsection{Measurement Model Assessment}

Two constructs designed to measure the impact of positive and negative manager behaviors on trust are included in the SEM model. The positive behavior constructs included the five items measures identified in the linear regression as positively impacting trust (see Table 3). The negative behavior construct included two negative behavioral items. The item measures and factor loadings along with the reliability values for the constructs are presented in Table 4. All factor loadings were statistically significant at $p<.01$ (Anderson \& Gerbing, 1988) and exceeded the minimum threshold of .5 recommended by Hair et al. (2006, p. 777). The construct reliabilities for the positive behavior constructs exceeded the minimum threshold of .70 at .91 and the negative behavior construct was close at .69 (Hair, et al., 2006, p. 779). The average variance extracted (AVE) for both constructs exceeded the recommended threshold of .50 (Fornell and Larcker, 1981). These results provide evidence that the measurement model is valid.

Table 4. Individual Item Reliabilities, Construct Reliability, and AVE

\begin{tabular}{lcc}
\hline Items & Item reliabilities & AVE \\
\hline Positive Behaviors & $\mathbf{. 9 1}$ & $\mathbf{. 6 8}$ \\
Treat employees fairly and consistently & .86 & \\
Is ethical & .81 \\
Encourages employee growth / development & .78 \\
Promotes work life balance & .80 \\
Positively influences culture & .88 \\
Negative Behaviors & $\mathbf{. 6 9}$ & \\
Creates hostile or fearful work environments. & .72 \\
Is ineffective & .73 & \\
\hline
\end{tabular}

Note: Composite reliabilities in bold.

\subsection{Structural Equation Modeling Assessment}

The SEM model included the positive and negative constructs along with employee gender (see figure 1). The fit indices for the structural model demonstrate a good fit with $\chi^{2}=63.98$, GFI $=.97, \mathrm{AGFI}=.94, \mathrm{NFI}=.97, \mathrm{RFI}=.96$, IFI $=.95$, $\mathrm{TLI}=.99, \mathrm{CFI}=.98$, and RMSEA $=.064$ (Hu \& Bentler, 1999). The model and results are reported in Figure 1. The positive behavior construct shows a statistically significant positive influence $(p<.01)$ on employees' perceptions that firm managers are trustworthy. In contrast, the negative trait construct was not statistically significant on employees' perceptions that firm managers are trustworthy. Additionally, employees' gender had a statistically significant negative influence ( $\mathrm{p} .<.05)$ on employees' perceptions that firm managers are trustworthy. Gender is a binary variable with male coded at 2 and female as 1 . Because the beta is negative (-.04), this indicates that males are slightly less inclined than females to perceive their managers as trustworthy. 


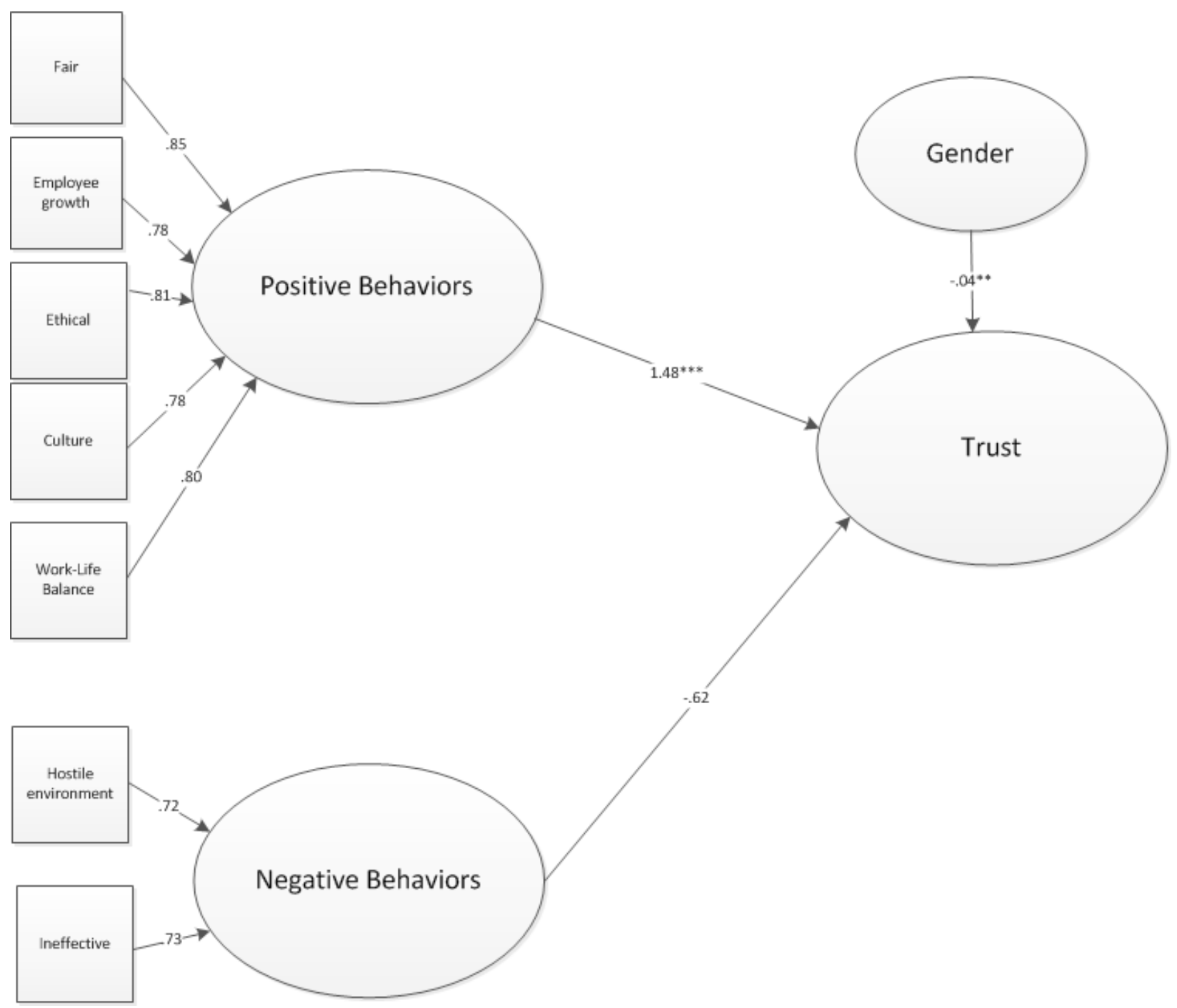

$* * \mathrm{p}<.05, * * * \mathrm{p}<.001$

Figure 1. Structural Model

Note: Standardized regression weights are reported.

\section{Discussion and Implications}

Our purpose has been to add to the existing literature on leadership, specifically in terms of how the concept of trust relates to perceptions of effective leadership. We tested empirically what specific behaviors are significant from the perspective of followers' in terms of creating trust between the manager and the employee, and believe we have unveiled some important insights into how leaders can build trust with followers.

The same concept for a specific behavior may be described semantically in various ways. That is, various behavioral descriptions and terms can be utilized to capture the same concept. Previous researchers have described virtually the same conceptual behavior via different words in various studies. Consequently, we attempt to reconcile the different terms that have been used in other research to convey the same behavioral concept. 


\section{Positive Behaviors}

\subsection{Treats Employees Fairly}

As with the other variables in the model, the concept of fair treatment is quite broad. The idea of equitable treatment has been recognized as a behavior important to leadership (Dirks \& Ferris, 2002; Gordon \& Gilley, 2012; Sitkin, et al., 2007).

The concept of equitable treatment is anchored in attitudes reflected by compassion, care and/or concern. These attitudes have been noted in other research (Gilley \& Gilley, 2007; Jung \& Avolio, 2000; Kent et al, 2007; Sitkin et al, 2007). Furthermore, compassion, care, and concern often produce benevolent actions by the leader, which other research has noted as assisting with the creation of trust (Brower, et al., 2000; Burke, et al., 2007; Mayer, et al., 1995).

Gilley, Anderson, and Gilley (2008) suggest that to create competitive advantage through people and processes, organizations adopt the principles and practices that enable them to treat their employees as their most valuable component in achieving greater success. This approach nourishes an organization's capability through state-of-the-art human resource practices. Gilley and Maycunich (1999) contend that building competencies in people and organizations requires managers to focus on enhancing human resource planning, improving motivation, recruiting, and selection, recognizing and rewarding employee growth and development, understanding legal issues in human resources, implementing career and professional development strategies, providing performance coaching and performance appraisal activities as a means of improving performance management systems, engaging in organizational development and ethical decision-making, and leadership and strategic planning initiatives. Accordingly, organizations that adopt these principles, practices, and ideas will face situations in which managers will need a framework that will improve their trust and leadership capabilities.

\subsection{Encouraging Employee Growth and Development}

Followers in our sample perceive their managers' encouragement of their growth and development as a significant attribute for developing trust in leadership. Encouragement of employees can also be considered a behavior associated with motivation, which has been previously identified as important to leadership (De Pree, 1989; Gillespie \& Mann, 2004).

Encouraging employee growth implies that managers assist employees in their development. Such assistance is a characteristic of servant-leadership, which has been noted as a set of leadership behaviors that lead to trust (De Pree, 1989; Greenleaf, 1977; Russell \& Stone, 2002).

Gilley, Shelton, and Gilley (2011) believe that managers will need to adopt the principles and practices of developmental leadership to improve the growth and development of their employees. Developmental leadership is the process of equipping people with the knowledge, skills, and opportunities they need to develop themselves and become more effective. Further, developmental leadership occurs whenever the relationship between leaders and employees has the opportunity to improve. McIntyre (2010) suggests that developmental leadership involves creating a synergistic relationship with employees, the primary benefit of which is the establishment of a collegial partnership. This partnership is based on two-way communication, trust, honesty, and interaction, and should be non-judgmental, free of fear, personal, and professional (Gilley, Shelton, \& Gilley, 2011). Additionally, developmental leadership allows managers the opportunity to better serve their employees through a variety of activities such as integrated communications, developmental evaluations, reward and recognition systems, and performance growth and development activities (McIntyre, 2010).

Developmental leadership provides organizations and their employees with creative, safe outlets through which to provide innovative and creative solutions to complex problems (Stone, 1999). It enables organizations to identify and incorporate new ideas, processes, or procedures that help them rebuild their market share and create successful business strategies. Developmental leadership is a process of ultimate sharing, providing leaders the opportunity to unlock the mysteries of the organization for their employees (McIntyre, 2010). Developmental leadership helps employees avoid political landmines and costly mistakes while allowing them to adjust to the organization's culture and better assimilate into the work environment (Gilley, et al 2011).

Developmental leadership is also based on awareness, which is the product of focused attention, concentration, and clarity on the part of the leader (Gilley, Gilley, \& McMillan, 2009). According to McIntyre (2010), awareness implies having knowledge of something through alertness in observing or in interpreting what one observes, feels, and hears.

Responsibility is another key element of developmental leadership due to its influence on employee performance. When employees accept, choose, or take responsibility for their thoughts and actions, the organization's commitment 
to them rises and so does their performance (Gilley, et al Gilley, 2011). When employees are ordered to be responsible, their acceptance may be low, which negatively impacts their performance.

\subsection{Ethical Behavior}

This variable was the most significant in the model with respect to impact on trust in the employee's manager. Previous research has found ethical behavior to be important in creating trust in professional relationships, however, these studies used slightly different terms to describe ethical behavior, including integrity (Brower, et al., 2000; Burke, et al., 2007), honesty (Gilley, 2006), and credibility (Farling, et al., 1999).

Anderson, and Gilley (2008), one's ethical lens develops through his or her family, education, relationships, and life experiences. As a result, managers and employees each possess different standards of and approaches to ethics.

The principal concern of organizational managers should be their people, and the policies that affect their growth, development, and performance. Each of these can create ethical dilemmas as managers balance what is in the best interest of the organizations and its people (Handelsman, Gottlieb, \& Knapp, 2005). Consequently, managers become responsible for helping resolve such ethical dilemmas. Managers also must balance the tension of their own values and ethics and those of the organization by developing a professional ethical identity (Handelsman et al., 2005), which is resolved through marginalization, separation, assimilation, or integration. Ulrich and Brockbank (2005) believe that chances of successfully adopting an integration strategy improve dramatically when managers have developed short and long-term plans that keep attention focused on ethical decision making practices along with their values and benefits. In short, managers create an enduring, integrated ethical decision-making action plan when they implement successful ethical decision-making processes (Gilley, et al, 2008).

\subsection{Positively Influences Culture}

The next most significant variable in the model relates to the concept of the manager's ability to positively influence organizational culture. This ability is linked to vision, which has been found to be characteristic of effective leadership in other research (Gillespie \& Mann, 2004; Gordon \& Gilley, 2012; Kouzes \& Posner, 1993; Podsakoff, et al., 1990).

Influencing culture implies social interactions and a social process, which has been posited as an important part of leadership (Griffin \& Stacey, 2005). Additionally, Martin (1999), Gilley (2006) and Gordon and Gilley (2012) see genuine personal relationships and involvement with followers as characteristic of effective leaders, which can enhance social capital (Adler \& Kwon, 2002).

\subsection{Work-life Balance}

According to Twenge \& Campbell (2008), work-life balance is an increasingly studied topic, particularly in light of generational differences. Twenge (2010) found that GenY/GenMe employees gravitate to companies that focus on work-life balance issues, which increases trust between managers and employees (Chao, 2005; Wong, Gardiner, Lang, $\&$ Coulon, 2008).

Findings of our study suggest that the manager is a key factor in establishing work-life balance, which builds trust among employees. Several scholars have recorded that managerial support, communication, and understanding are critical to employees' achievement of work/family balance (Anderson et al., 2002; Batt \& Valcour, 2003; Clark, 2002; Eversole, Venneberg, \& Crowder, 2012). Eversole et al. (2012) claim "an insensitive and inflexible manager increases tension, decreases productivity, has the single most negative influence on work-life, and makes the whole company look insensitive" (p. 615).

Collins, Hair, and Rocco (2009) further claim that the trust relationship can be enhanced with knowledge of generational differences and the contrasting work values of each generation (Eversole et al., 2012). Watkins (1995) declared that the supervisor-subordinate relationship is one of the most powerful predictors of work/family problems and if negative can seriously affect trust. Thompson, Beauvais, \& Lyness (1999) found two factors associated with what they termed as work-family culture that lead to improved trust between managers and employees. The first factor is managerial support, which is defined as "the extent to which managers were supportive and sensitive to employees' family responsibilities" (p. 401). The second is known as the contextual factors in which the establishment of work-life policies that encourage managerial support leads to better trust relationships. 


\section{Negative Behaviors}

\subsection{Managers Create Hostile or Fearful Work Environments}

Gilley, Anderson, and Gilley (2008) contend that trust cannot be established when managers create hostile or fearful work environments. A hostile work environment creates self-defeating and dysfunctional behavior on the part of employees (Hardy \& Schwartz, 2006). Scott (2005) reported hostility and fear based work environments are commonly characterized by reprisals and intimidation. Such environments cause unhappiness, anger, and resentment on the part of employees. He also contends that hostile and fearful work environments are not conductive to establishing trust between managers and employees.

Scott (2005) asserts that such behaviors are based on two types of fear, which are mythical and realistic. Mythical fears, although unsubstantiated or unrealistic, are destructive to organizations when they prevent adoption of performance improvement strategies. Realistic fears are based on fact, not destructive or paranoid organizational self-talk. Gilley, Anderson, and Gilley (2008) suggests that realistic fears can be managed and addressed through proactive actions designed to avoid over-reactive, counter-productive responses to unknown or unsubstantiated perceptions.

According to Gilley and Hoekstra (2003), work environments that are free of hostility and fear allow managers and employees to communicate, work collectively together, and take risks. Under these conditions creativity flourishes and employees are challenged and encouraged to solve complex problems. This allows managers and employees the opportunity to build a mutually beneficial, positive relationship. Shelton, Waite, and Makela (2011) suggest that managers may also be surprised at the effects such encouragement will have on employee morale, attitudes, and overall commitment.

\subsection{Managers are Ineffective}

According to our finding, managers who lack the supervisory and managerial skills to be effective are perceived as having a negative effect on trust. It has been well documented that many managers:

- have poor listening, feedback, and interpersonal relationship skills;

- cannot delegate;

- do not develop their employees;

- fail to conduct effective performance appraisals;

- do not establish positive relationship with their employees; and/or

- do not establish priorities.

Organizations select them anyway (Donlevy \& Walker, 2011; Gilley, Gilley, \& McMillan, 2009; Robbins \& Judge, 2010; Shelton, Waite, \& Makela, 2011). Gilley and Gilley (2009) suggest that these are symptoms of managerial malpractice within organizations, which are the result of:

- hiring or promoting managers who lack the understanding and skills necessary to effectively manage others;

- hiring or promoting managers because they are the "best performers" or "highest producers" and without regard for their interpersonal skills;

- wasting valuable time and resources attempting to "fix" ineffective or incompetent managers; and/or

- failing to reprimand, demote, or fire managers who are ineffective or incompetent (p.343).

Donlevy and Walker (2011) believe the solution to improving the ethical perceptions of managers, which enables organizations to also overcome managerial malpractice, is simple. Organizations should select managers for their people skills and hold them accountable for securing results through people. Gilley and Boughton (1996) contend that organizations that select and promote managers who are ineffective encourage and foster managerial malpractice, which is defined as encouraging and supporting practices that enable unprofessional, unproductive, and incompetent managers to function within an organization (p. 15).

\section{Gender}

Throughout modern history the overwhelming majority of managers have been white, affluent males from similar backgrounds and life experiences (Gilley, Eshbach, Kouider, and Gilley, 2013). Even in today's culture, the prevalent attitude, rightly or wrongly, is that men make better leaders and better supervisors than women (Duerst-Lahti \& Kelly 
1995; Kanter 1977; Stivers, 2002). Kabacoff (1998) postulates that men are perceived as more innovative, restrained, and persuasive, and are typically viewed as more likely to grasp organizational vision and strategic planning.

According to Conlin (2003), females are usually rated higher by their subordinates when compared to their male counterparts. Studies have shown that female managers are generally more helpful, which results in more effective coaching and development (Burke \& Collins, 2001; Eagly \& Johnson, 1990). Gilley, Eshbach, Kouider, and Gilley (2013) reported that women were rated as more communicative and empathetic, and were viewed as more democratic, interactive, and conscious of the needs of others. Other research indicates that women may have an advantage over men in certain aspects of effective leadership (Anderson, Lievens, van Dam, \& Born, 2006; Eagly, Johannesen-Schmidt, \& Van Engen, 2003). Moore, Grunberg, and Greenberg (2004) found that there were benefits to working for a female supervisor for both men and women. Similarly, Kabacoff (1998) found that female managers score higher on leadership oriented toward production.

\section{Limitations}

Our study is subject to several limitations, most of which involve the potential ambiguity of language and imprecise measurement of respondent opinions. Terms such as 'trust' or 'ethics' may hold vastly different meanings for individuals. What constitutes moral or ethical behavior for one person may not be the same for another, just as 'trust' may surface a range of expectations, emotions, or behaviors depending on the person and the situation. Further, our research solicited employees' perceptions of their managers' behaviors and effectiveness, which yields highly subjective opinions filtered through participants' understanding of terminology, biases and stereotypes, experiences, and potentially inaccurate or incomplete information (Burke, Sims, Lazarra, \& Salas, 2007).

Our research relied on self-ratings, imprecise measures, and perceptual data, which leads to concerns about methods variance and attribution bias. Self-selection has been shown to skew results (Podsakoff, et al., 2003); consequently we utilized multiple groups at differing locations to lessen this threat. The self-rating, convenience sampling methodology used in this research may also detract from our ability to generalize results. Graduate students in MBA and OD Master's and Ph.D. programs may not reflect the composition of the population in a manner that yields transferrable conclusions.

Finally, multi-level or cross-level effects are not reflected or measured in this study. The intensity of interaction with a manager, or the ripple effect of trust on specific aspects of one's work, may impact some employees more than their colleagues. Consequently, the impact of trust on the worker or work environment may be felt more keenly by some employees than others.

\section{Recommendations for Future Research}

Opportunities for additional research related to subordinate perceptions of managerial trust are abundant. The model and its implications may be enriched by testing the degree and direction of interaction among variables, and by examining the influence of additional participant demographics (e.g., tenure within an organization) on perceptions of trust.

Also, scales have been developed and validated for the purpose of measuring trust (Robinson, 1996). The results of our model could be used to develop more recent and focused scales based on perceptions of employees concerning trust in management. Those scales would have use in measurement of trust levels within organizations.

Finally, trust has been long thought of as providing favorable outcomes in terms of organizational effectiveness and commitment. There is potential for examining trust, as measured by our results, against both organizational commitment and effectiveness.

\section{Conclusion}

Our model purports to represent the behaviors that are perceived by followers to establish trust in their leaders. Managers who are ethical, positively influence culture, encourage employee growth and development, treat employees fairly and consistently, and promote work-life balance are perceived by their followers as trustworthy. Ethics/integrity and fairness toward others have been previously associated with trust in managers. We contribute to the literature by identifying culture, employee growth and development, and promoting work-life balance as significant influencers on perceptions of trust in management. 


\section{References}

Adler, P. S., \& Kwon, S. (2002). Social Capital: Prospects for a New Concept. Academy of Management Review, 27(1), 17-40.

Anderson, N., Lievens, F., van Dam, K., \& Born, M. (2006). Journal of Applied Psychology, 91(3), 555-566. http://dx.doi.org/10.1037/0021-9010.91.3.555

Anderson, S. E., Coffey, B. S., \& Byerly, R. T. (2002). Formal organizational initiatives and informal workplace practices: Links to work-family conflict and job related outcomes. Journal of Management, 28, 787-811.

Bass, B. M. (1990). Bass and Stogdill's handbook of leadership: Theory, research and managerial applications $\left(3^{\text {rd }}\right.$ edition.). New York: Free Press.

Batt, R., \& Valcour, P. M. (2003). Human resource practices as predictors of work-family outcomes and employee turnover. Industrial Relations, 42, 189-220.

Baxter, J., \& Wright, E. (2000). The glass ceiling hypothesis: A comparative study of the United States, Sweden, and Australia. Gender \& Society, 14, 275-294. http://dx.doi.org/10.1177/089124300014002004

Bijlsma, K., \& Koopman, P. (2003). Introduction: trust within organizations. Personnel Review, 23(5), 543-555. http://dx.doi.org/10.1108/00483480310488324

Blau, P. M. (1964). Exchange and power in social life. New York: Wiley.

Brower, H. H., Schoorman, F. D., \& Tan, H. H. (2000). A model of relational leadership: The integration of trust and leader-member exchange. The Leadership Quarterly, 11(2), 227-250. http://dx.doi.org/10.1016/S1048-9843(00)00040-0

Burke, C. S., Sims, D. E., Lazarra, E. H., \& Salas, E. (2007). Trust in leadership: A multi-level review and integration. The Leadership Quarterly, 18(6), 606-632. http://dx.doi.org/10.1016/j.leaqua.2007.09.006

Burke, S., \& Collins, K. (2001). Gender differences in leadership styles and management skills. Women in Management Review, 16, 244-57. http://dx.doi.org/10.1108/09649420110395728

Butler, J. K. (1991). Toward understanding and measuring conditions of trust: Evolution of a conditions of trust inventory. Journal of Management, 17(3), 643-663. http://dx.doi.org/10.1177/014920639101700307

Chao, L. (2005). For Gen Xers, it's work to live: Allowing employees to strike balance between job and life can lead to better retention rates. The Wall Street Journal, Eastern edition, November 29, B6.

Clark, S. C. (2002). Communicating across the work/home border. Community, Work and Family, 5, 23-49. http://dx.doi.org/10.1080/13668800020006802

Collins, M. H., Hair, J. F., \& Rocco, T. S. (2009). The older-worker - younger-supervisor dyad: A test of the reserve Pygmalion effect. Human Resource Development Quarterly, 20, 21-41. http://dx.doi.org/10.1002/hrdq.20006

Conlin, M. (2003, May 26). The new gender gap. Business Week, 74-82.

Curral, S. C., \& Judge, T. A. (1995). Measuring trust between organizational boundary role persons. Organizational Behavior and Human Decisions, 64(2), 151-170. http://dx.doi.org/10.1006/obhd.1995.1097

De Pree, M. (1989). Leadership is an art. New York: Dell Publishing.

Dienesch, R. M., \& Liden, R. C. (1986). Leader-member exchange model of leadership: A critique and further development. Academy of Management Review, 11(3), 618-634.

Dirks, K. T., \& Ferrin. D. L. (2002). Trust in leadership: Meta-analytic findings and implications for research and practice. Journal of Applied Psychology, 87(4), 611-628. http://dx.doi.org/10.1037/0021-9010.87.4.611

Donlevy, J. K., \& Walker, K. D. (2011). Working through ethics in education and leadership. Sense Publishers. http://dx.doi.org/10.1007/978-94-6091-376-1

Duerst-Lahti, G., \& Kelly, R. (1995). Gender, power, leadership and governance. Ann Arbor: The University of Michigan Press.

Eagly, A. (2007). Female leadership advantage and disadvantage: Resolving the contradictions. Psychology of Women Quarterly, 3(1), 1-12. http://dx.doi.org/10.1111/j.1471-6402.2007.00326.x

Eagly, A. H., \& Johnson, B, T. (1990). Gender and leadership style: A meta-analysis. Psychological Bulletin, 108, $233-256$. 
Eagly, A., Johannesen-Schmidt, M., \& Van Engen, M. (2003). Transformational, transactional, and laissez-faire leadership styles: A meta-analysis comparing women and men. Psychological Bulletin, 129, 569-591. http://dx.doi.org/10.1037/0033-2909.129.4.569

Eversole, B. A. W., Venneberg, D. L., \& Crowder, C. L. (2012). Creating a flexible organizational culture to attract and retain talented workers across generations. Advances in Developing Human Resources, 14(4), 607-625. http://dx.doi.org/10.1177/1523422312455612

Fairholm, G. W. (1994). Leadership and the culture of trust. Westport, CT: Praeger.

Farling, M. L, Stone, A. G., \& Winston, B. E. (1999). Servant leadership: Setting the stage for empirical research. The Journal of Leadership Studies, 6(1), 49-72. http://dx.doi.org/10.1177/107179199900600104

Fukuyama, F. (1997). Social capital and the modern capitalist economy: Creating a high-trust workplace. Stern Business Magazine, 4(1), 1-16.

Gillespie, N., \& Mann, L. (2004). Transformational leadership and shared values: The building blocks of trust. Journal of Managerial Psychology, 19(6), 588-607. http://dx.doi.org/10.1108/02683940410551507

Gilley, A., \& Gilley, J. W. (2009). Managerial malpractice. In A. Gilley, J. W. Gilley, S. Quatro, and P. Dixon, The Praeger Handbook of Human Resource Management and Workplace Policy. Vol. 2, (342-345), Westport, CT: Praeger Publishers.

Gilley, A., Eshbach, L., Kouider, E., \& Gilley, J. W. (2013). Gender difference when leading change. Journal of Scholastic Inquiry: Business, 1(1), 104-128.

Gilley, A., McMillan, H. S., \& Gilley, J. W. (2009). Organizational change and characteristics of leadership effectiveness. Journal of Leadership and Organizational Studies, 16(1), 38-47. http://dx.doi.org/10.1177/1548051809334191

Gilley, J. W. (2006). Manager as politician. Hartford, CT: Praeger Publishing.

Gilley, J. W., \& Boughton, N. W. (1996). Stop managing, Start coaching: How performance coaching can enhance commitment and improve performance. New York: McGraw-Hill Professional Publishing.

Gilley, J. W., \& Gilley, A. (2007). Manager as coach. Hartford, CT: Praeger Publishing.

Gilley, J. W., \& Hoekstra, E. (2003). Creating a climate for learning transfer. In E. Holton III, \& T. Baldwin. Learning transfer. For the Society of Industrial Psychology. San Francisco: Jossey Bass.

Gilley, J. W., \& Maycunich, A. (2000). Beyond the learning organization: Creating a culture for growth and development through state of-the-art HR practices. Cambridge, MA: Perseus Publishing.

Gilley, J. W., Anderson, S., \& Gilley A. (2008). Human resources management as a champion for corporate ethics: Moving ethical integration and acculturation in the HR function and profession. In S. Quatro and R. Sims, Executive ethics: Ethical dilemmas and challenges for the C-suite. (pp. 191-213), Armonk, NY: M. E. Sharpe, Inc.

Gilley, J. W., Shelton, P. M., \& Gilley, A. (2011). Developmental leadership: A new perspective for HRD. Advances in Human Resource Development, 13(3), 386-405. http://dx.doi.org/10.1177/1523422311424264

Gordon, G. (2010). Managing in Mexico - An ethnographic comparison to theory and previous research. Journal of International Business and Cultural Studies, 2, 74-84.

Gordon, G., \& Gilley, J. W. (2012, August). A trust-leadership model. Performance Improvement Journal, 5(7), $28-35$. http://dx.doi.org/10.1002/pfi.21284

Greenleaf, R. K. (1977). Servant leadership: A journey into the nature of legitimate power and greatness. Mahway, NJ: Paulist Press.

Griffin, D., \& Stacey, R. (2005). Complexity and the experience of leading organizations. New York: Routledge.

Guadagno, R., \& Cialdini, R. (2007). Gender differences in impression management in organizations: A qualitative review. Sex Roles, 56(7-8), 483-494. http://dx.doi.org/10.1007/s11199-007-9187-3

Handelsman, M.M., Gottlieb, M.C., \& Knapp, S. (2005). Training ethical psychologists: An acculturation model. Professional Psychology: Research and Practice, 36(1), 59-65. http://dx.doi.org/10.1037/0735-7028.36.1.59

Harvey, R. E., \& Schwartz, R. (2006). The self-defeating organization: How smart companies can stop outsmarting themselves $\left(2^{\text {nd }}\right.$ ed.). Reading: MA Perseus. 
Heilman, M. (2001). Description and prescription: How gender stereotypes prevent women's ascent up the organizational ladder. Journal of Social Issues, 57, 657-674. http://dx.doi.org/10.1111/0022-4537.00234

Hogan, R., Curphy, G., \& Hogan, J. (1994). What we know about leadership: Effectiveness and personality. American Psychologist, 49(6), 493-504. http://dx.doi.org/10.1037/0003-066X.49.6.493

Jung, D., \& Avolio, B. (2000). Opening the black box: An experimental investigation of the mediating effects of trust and value congruence on transformational and transactional leadership. Journal of Organizational Behavior, 21(8), 949-964. http://dx.doi.org/10.1002/1099-1379(200012)21:8<949::AID-JOB64>3.0.CO;2-F

Kabacoff, R. (1998). Gender differences in organizational leadership. Portland, ME: Management Research Group.

Kanter, R. (1977). Men and women of the corporation. New York, NY: Basic Books.

Kent, T. W., Crotts, J. C., \& Aziz, A. (2001). Four factors of transformational leadership behavior. Leadership and Organizational Development Journal, 22(5/6), 221-229. http://dx.doi.org/10.1108/01437730110396366

Kirkpatrick, S. A., \& Locke, E. A. (1996). Direct and indirect effects of three core charismatic leadership components on performance and attitudes. Journal of Applied Psychology, 81(1), 36-51. http://dx.doi.org/10.1037/0021-9010.81.1.36

Kouzes, J. M., \& Posner, B. Z. (1993). Leadership practices inventory. San Diego: Pfeiffer and Co.

Kramer, R. M. (1999). Trust and distrust in organizations: Emerging perspectives, enduring questions. Annual Review of Psychology, 50(1), 569-599. http://dx.doi.org/10.1146/annurev.psych.50.1.569

LaPorta, R., Lopez-de-Silanes, F., Shleifer, A., \& Vishny, R. W. (1997). Trust in large organizations. The American Economic Review, 87(2), 333-339.

Lyness, K., \& Thompson, D. (2000). Climbing the corporate ladder: Do female and male executives follow the same route? Journal of Applied Psychology, 85, 86-101. http://dx.doi.org/10.1037/0021-9010.85.1.86

Martin, M. M. (1999). Trust Leadership. Journal of Leadership and Organizational Studies, 5(3), 42-49. http://dx.doi.org/10.1177/107179199900500304

Maume, D. (2004). Is the glass ceiling a unique form of inequality? Evidence from a random-effects model of managerial attainment. Work and Occupations, 31, 250-274. http://dx.doi.org/10.1177/0730888404263908

Mayer, R. C., \& Gavin, M. (1999). Trust for management and performance: Who minds the shop while the employees watch the boss? 1999 Annual Meeting of the Academy of Management.

Mayer, R. C., Davis, J. H., \& Schoorman, F. D. (1995). An integrative model of organizational trust. Academy of Management Review, 20, 709-734.

McIntyre, M. G. (2010). Developmental leadership. Retrieved from yourofficecoach.com

Moore, S., Grunberg, L., \& Greenberg, E. (2004). Development and validation of a scale to measure beliefs about women managers. Current Psychology, 23(3), 245-256. http://dx.doi.org/10.1007/s12144-004-1024-z

Munn, A.K. (1995). Potential influence of trust on the successful completion of a project. International Journal of Project Management, 13(1), 19-24. http://dx.doi.org/10.1016/0263-7863(95)95699-E

Nunally, I. H., \& Bernstein, J. C. (1994). Psychometric Theory ( $3^{\text {rd }}$ ed.). New York: McGraw-Hill.

Pillai, R., Schriesheim, C., \& Williams. E. (1999). Fairness perceptions and trust as mediators of transformational and transactional leadership: A two sample study. Journal of Management, 25(6), 897-933. http://dx.doi.org/10.1177/014920639902500606

Podsakoff, P. M., MacKenzie, S. B., Lee, J. Y., \& Podsakoff, N. P. (2003). Common method biases in behavioral research: A critical review of the literature and recommended remedies. Journal of Applied Psychology, 88(5), 879-903. http://dx.doi.org/10.1037/0021-9010.88.5.879

Podsakoff, P. M., MacKenzie, S. B., Moorman, R. H., \& Fetter, R. (1990). Transformational leader behaviors and their effects on followers' trust in leader, satisfaction, and organizational citizenship behaviors. Leadership Quarterly, 1(2), 107-147. http://dx.doi.org/10.1016/1048-9843(90)90009-7

Portes, A. (1998). Social capital: Its origins and applications in modern society. Annual Review of Sociology, 24, 1-24. http://dx.doi.org/10.1146/annurev.soc.24.1.1

Putnam, R. D. (1993). Making democracy work: Civic traditions in modern italy. Princeton, NJ: Princeton University 
Press.

Robbins, S. P., \& Judge, T. A. (2010). Essentials of organizational behavior(10 ${ }^{\text {th }}$ eds.). Upper Saddle River, NJ: Prentice Hall.

Robinson, S.L. (1996). Trust and breach of the psychological contract. Administrative Science Quarterly, 41(4), 574-600. http://dx.doi.org/10.2307/2393868

Rousseau, D.M., Sitkin, S.B., Burt, R. S., \& Camerer, C. (1998). Not so different at all: A cross-discipline view of trust. Academy of Management Review, 23(3), 393-404. http://dx.doi.org/10.5465/AMR.1998.926617

Russell, R. F., \& Stone, A. G. (2002). A review of servant leadership attributes: Developing a practical model. Leadership and Organization Development Journal, 23(3), 145-157. http://dx.doi.org/10.1108/01437730210424

Schriesheim, C., Castro, S., \& Cogliser, C. (1999). Leader-member exchange (LMX) research: A comprehensive review of theory, measurement and data-analytic procedures. Leadership Quarterly, 10(1), 63-113. http://dx.doi.org/10.1016/S1048-9843(99)80009-5

Scott, E. D. (2005). The ethics of human resource management. In J. W. Budd and J. G. Scoville, The ethics of human resources and industrial relations (pp. 173-202). Charlotte, NC: Information Age Publishing.

Sharkie, R. (2009). Trust in leadership is vital for employee performance. Management Research News, 32(5), 491-498. http://dx.doi.org/10.1108/01409170910952985

Shelton, P. M., Waite, A. M., \& Makela, C. J. (2011). Highly effective teams: A Relational analysis of group potency and perceived organizational support. Advances in Human Resource Development, 13(3), 93-114.

Sitkin, S. B., Hernandez, M., \& Long, C. P. (2007). Cultivating trust in leaders: Are all leader behaviors equally influential? Working paper, Duke University.

Stivers, C. (2002). Gender images in public administration: Legitimacy and the administrative state. Thousand Oaks, California: Sage Publications.

Stone, F. M. (1999). Developmental leadership, counseling, and developmental leadership: How to choose and use the right technique to boost employee performance. New Work: AMACOM.

Thompson, C. A., Beauvais, L. L., \& Lyness, K. S. (1999). When work-family benefits are not enough: The influence of work-family culture on benefit utilization, organizational attachment, and work-family conflict. Journal of Vocational Behavior, 54, 392-415. http://dx.doi.org/10.1006/jvbe.1998.1681

Timberlake, S. (2005). Social capital and gender in the workplace. Journal of Management Development, $24,34-44$. http://dx.doi.org/10.1108/02621710510572335

Twenge, J. M. (2010). A review of the empirical evidence on generational differences in work attitudes. Journal of Business Psychology, 25, 201-210. http://dx.doi.org/10.1007/s10869-010-9165-6

Twenge, J. M., \& Campbell, S. M. (2008). Generational differences in psychological traits and their impact on the workplace. Journal of Managerial Psychology, 23, 862-877. http://dx.doi.org/10.1108/02683940810904367

Tyler, T. (2003). Trust within organizations. Personnel Review, 32(5), 556-568. http://dx.doi.org/10.1108/00483480310488333

Ulrich, D., \& Brockbank, W. (2005). The HR value proposition. Cambridge, MA: Harvard Business School Press.

Vogt, W. P. (2005). Dictionary of statistics and methodology: A nontechnical guide for the social sciences (3 ${ }^{\text {rd }}$ ed.). Thousand Oaks, CA: Sage.

Watkins, K. E. (1995). Changing managers' defensive reasoning about work/family conflicts. Journal of Management Development, 14(2), 77-88. http://dx.doi.org/10.1108/02621719510078911

Wong, M., Gardiner, E., Lang, W., \& Coulon, L. (2008). Generational differences in personality and motivation: Do they exist and what are the implications for the workplace? Journal of Managerial Psychology, 23, 878-890. http://dx.doi.org/10.1108/02683940810904376

Zand, D. E. (1972). Trust and managerial problem solving. Administrative Science Quarterly, 17, $229-239$. http://dx.doi.org/10.2307/2393957 